\title{
Urea-cored peptides for anion binding and vesicle formation
}

\author{
Ishanki Bhardwaj, Rachit Sapra, and V. Haridas* \\ Department of Chemistry, Indian Institute of Technology Delhi (IITD), Hauz Khas, \\ New Delhi-110016, India \\ E-mail: haridasv@chemistry.iitd.ac.in
}

DOI: https://doi.org/10.24820/ark.5550190.p009.876

\begin{abstract}
Urea and urea-triazole cored peptides were synthesized and characterized. These compounds were analyzed for their potency to sense anions such as $\mathrm{F}^{-}, \mathrm{Cl}^{-}, \mathrm{Br}^{-}, \mathrm{I}^{-}, \mathrm{H}_{2} \mathrm{PO}_{4}{ }^{-}$and $\mathrm{HSO}_{4}{ }^{-}$by $\mathrm{UV}_{\text {-vis }}$ and ${ }^{1} \mathrm{H}$ NMR spectroscopy. Urea-cored compounds showed very weak binding, while the ureatriazole containing compound showed high binding towards $\mathrm{H}_{2} \mathrm{PO}_{4}{ }_{4}^{-}$and $\mathrm{HSO}_{4}{ }^{-}$. The urea-triazole containing compound also acts as colorimetric sensor for $\mathrm{F}^{-}$and $\mathrm{H}_{2} \mathrm{PO}_{4}{ }^{-}$. Both classes of compounds favored vesicular assembly in $1: 1 \mathrm{CH}_{3} \mathrm{OH} / \mathrm{CHCl}_{3}$.
\end{abstract}

Keywords: Urea, anion recognition, colorimetric sensor, self-assembly, vesicles

\section{Introduction}

Anion sensing has attracted considerable attention due to the important roles of anions in chemistry, catalysis, medicine, biology, and environmental science. ${ }^{1-2}$ Therefore, considerable effort has been devoted to the design of receptors for anion binding and sensing. Anion binding is a great challenge because anions have different size, shape and charge and anion complexation is also $\mathrm{pH}$-dependent. ${ }^{1}$ Anion receptors can be positively charged or neutral; they bind anions mainly through hydrogen bonding and/or electrostatic interactions. Various neutral anion receptors which include scaffolds bearing amide, urea, pyrrole and triazole groups as binding sites have been reported. $^{3-10}$

The pioneering work of Wilcox ${ }^{11}$ and Hamilton ${ }^{12}$ showed that urea moiety can bind anions, in particular anion such as acetate. A variety of receptors containing a urea motif have been developed and studied for their anion sensing. ${ }^{13-17}$ Therefore, the urea unit has been taken as an excellent motif for the construction of anion receptors. The success of urea as a binding motif is due to the fact that it possesses two close $\mathrm{N}-\mathrm{H}$ units that can chelate a spherical anion in bifurcate hydrogen bonding mode, giving rise to a six-membered ring (Figure 1a). The two parallel H-bonds with two oxygen atoms of a carboxylate results in an eight-membered ring (Figure 1b). The high affinity of urea towards anion is due to spatially close H-bond donor sites. ${ }^{12}$ Appending amino acids on urea- 
based core can introduce additional H-bonding centers which can help in enhancing binding affinity towards anions. Amino acids containing functionalizable side chains provide an opportunity to design versatile receptors. Peptides with a urea core could be considered as a mimic of anion binding proteins. ${ }^{18}$

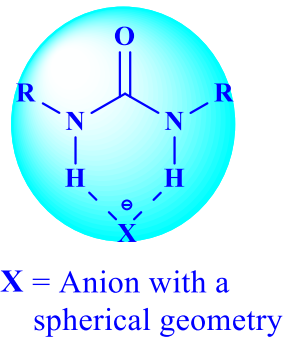

(a)

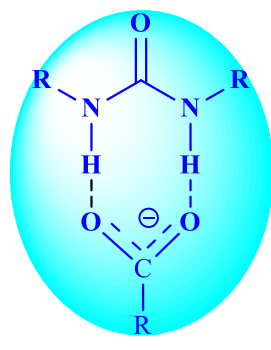

(b)

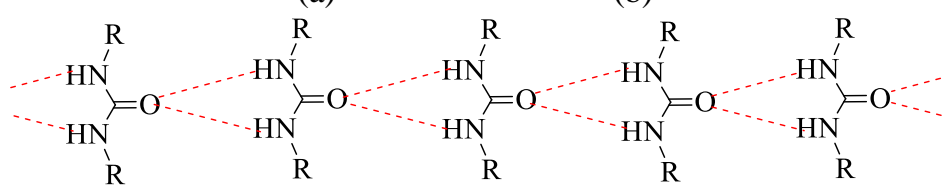

(c)

Figure 1. Mode of binding in urea-based molecules by formation of two parallel H-bonds (a) forming six-membered ring with spherical anion (b) forming eight-membered ring with a compound containing a carboxylate group ( $\mathrm{R}-\mathrm{COO}^{-}$) (c) Intermolecular hydrogen bonds in ureabased molecules.

In addition to providing NHs for binding to anions, the urea motif can form a supramolecular arrangement as a result of the urea $\alpha$-type hydrogen bonding pattern (Figure 1c) leading to distinct self-assembling features. Incorporation of amino acid residues can result in diverse supramolecular structures through additional non-covalent interactions. The hydrogen bonding capability of peptides can assist in forming specific supramolecular structures such as spheres, vesicles, fibers, helical ribbons and rods. ${ }^{19,20}$ The structurally modified urea derivatives have been extensively explored in organocatalysis, ${ }^{21,22}$ crystal engineering, ${ }^{23}$ supramolecular gelation, ${ }^{24-26}$ and as membrane transporters for anions. ${ }^{27}$

\section{Results and Discussion}

\section{Synthesis}

Herein, we report urea-cored and urea-triazole containing molecules 2, 4, 6 and 10. Compound 2 is based on L-tryptophan amino acid; $\mathbf{4}$ and $\mathbf{6}$ are based on dipeptide comprising L-tryptophan and L-leucine; $\mathbf{1 0}$ is a urea functionalized peptide consisting of additional triazole rings. Compound $\mathbf{2}$ was synthesized by reacting tryptophan methyl ester 1 with phosgene at $70-80{ }^{\circ} \mathrm{C}$. Similarly, 4 and 6 were synthesized by reacting the corresponding dipeptides such as $\mathrm{NH}_{2}$-Leu-Trp-OMe (3) and $\mathrm{NH}_{2}$-Trp-Leu-OMe (5) with phosgene (Scheme 1). 
<smiles>COC(=O)C(N)Cc1c[nH]c2ccccc12</smiles>

1<smiles>COC(=O)[C@H](Cc1c[nH]c2ccccc12)NC(=O)[C@H](CC(C)C)NC(=O)OCc1ccccc1</smiles>

(i) $\mathrm{Pd}-\mathrm{C} / \mathrm{H}_{2}, \mathrm{CH}_{3} \mathrm{OH}, 6 \mathrm{~h}$

(ii) $\mathrm{COCl}_{2}, 60-80{ }^{\circ} \mathrm{C}$, Dry $\mathrm{CH}_{2} \mathrm{Cl}_{2}$ $\mathrm{NEt}_{3}, 12 \mathrm{~h}$

(i) $\mathrm{Pd}-\mathrm{C} / \mathrm{H}_{2}, \mathrm{CH}_{3} \mathrm{OH}$, $6 \mathrm{~h}$

(ii) $\mathrm{COCl}_{2}, 60-80^{\circ} \mathrm{C}$, Dry $\mathrm{CH}_{2} \mathrm{Cl}_{2}$ $\mathrm{NEt}_{3}, 12 \mathrm{~h}$

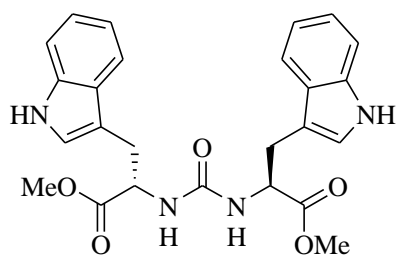

2

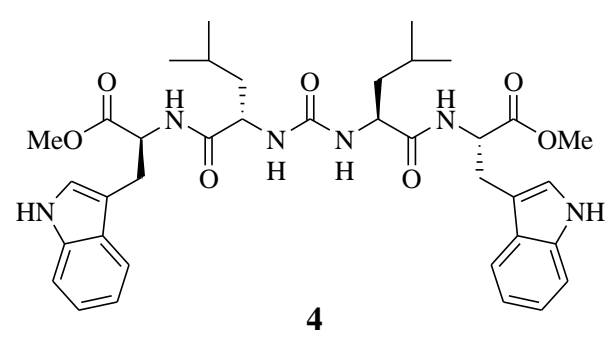

4<smiles>COC(=O)[C@H](CC(C)C)NC(=O)[C@H](Cc1c[nH]c2ccccc12)NC(=O)N[C@@H](Cc1c[nH]c2ccccc12)C(=O)N[C@@H](CC(C)C)C(=O)OC</smiles>

6

Scheme 1. Synthesis of urea functionalized molecules 2,4 and 6.<smiles>CCN(CC)C(=O)OC(=O)Cl</smiles>

7

8

(i) $4 \mathrm{~N} \mathrm{NaOH}$, distt.MeOH, $4 \mathrm{~h}$

8

(ii) $\widehat{\mathrm{NH}_{2}}$ Dry $\mathrm{CH}_{2} \mathrm{Cl}_{2}$

DCC, $\mathrm{HOSu}, \mathrm{NEt}_{3}, 0{ }^{\circ} \mathrm{C}$

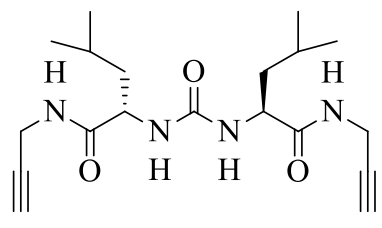

$9 \stackrel{p \text {-nitrophenylazide }}{\stackrel{\text { CuI, DIPEA, } \mathrm{CH}_{3} \mathrm{CN}}{\longrightarrow}}$

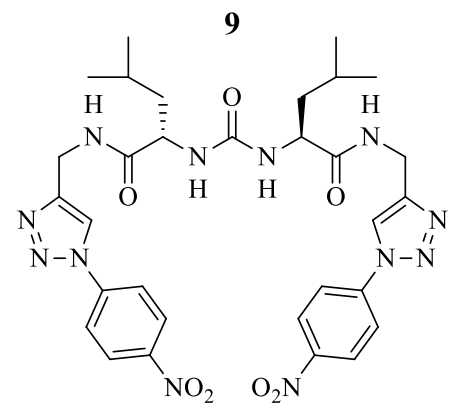

10

Scheme 2. Synthesis of triazole-based urea functionalized molecule $\mathbf{1 0}$. 
Compound 10 was synthesized by a different scheme (Scheme 2). First, urea derivative of L-leucine methyl ester (8) was prepared from $\mathrm{NH}_{2}$-Leu-OMe (7) using Scheme 1. Compound 8 was subjected to basic hydrolysis followed by reaction with propargylamine to give the dialkyne 9. Compound 9 was then reacted with $p$-nitrophenyl azide in the presence of $\mathrm{CuI}$ to give 1,2,3triazole containing compound 10. Introduction of Trp in place of Leu in $\mathbf{1 0}$ resulted in an insoluble compound.

\section{Anion binding studies}

These urea-cored and urea-triazole compounds provide an interesting class of molecules for anion binding and self-assembling studies. The scaffolds are functionalized with amino acid residues leucine and tryptophan. Tryptophan and triazole provide additional H-bond donors in the form of indole $\mathrm{NH}$ and $\mathrm{CH}$ respectively. Keeping in mind this concept, the binding efficiencies of the designed receptors were determined by UV-vis. and NMR spectroscopic techniques. UV-vis. and NMR titrations of 2 showed a very weak binding towards biphosphate with 1:1 stoichiometry (Figures S1 and S2). Compound $\mathbf{2}$ did not show much affinity towards other anions due to steric crowding by two indole units of Trp. The steric crowding around urea NHs is reduced in 4, in which Trp was replaced by the dipeptide L-Leu-Trp-OMe. UV-vis. and ${ }^{1} \mathrm{H}$ NMR titrations showed that 4 binds to acetate anion in 1:1 fashion (Figure 2, Figure S1) and for other anions, no observable changes in spectra were seen. The binding constant with $\mathrm{CH}_{3} \mathrm{COO}^{-}$in $\mathrm{CHCl}_{3}$ was calculated using 1:1 non-linear fit analysis ${ }^{28}$ (http://www.supramolecular.org) and was found out to be $115.53 \mathrm{M}^{-1}$ (Figure S2). ${ }^{1} \mathrm{H}$ NMR titration of 4 with acetate was carried out in $\mathrm{CDCl}_{3}$ (Figure 2). Addition of tetrabutylammonium acetate to 4 resulted in downfield shift of urea protons $(2.4 \mathrm{ppm})$, while the

(a)

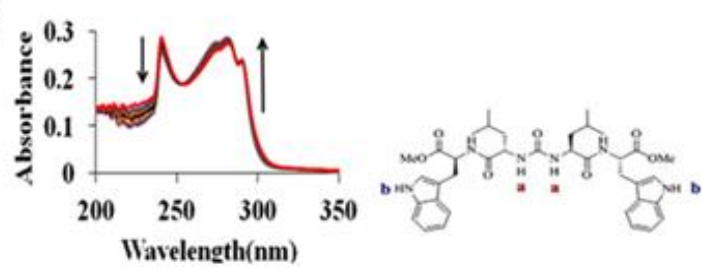

(b)

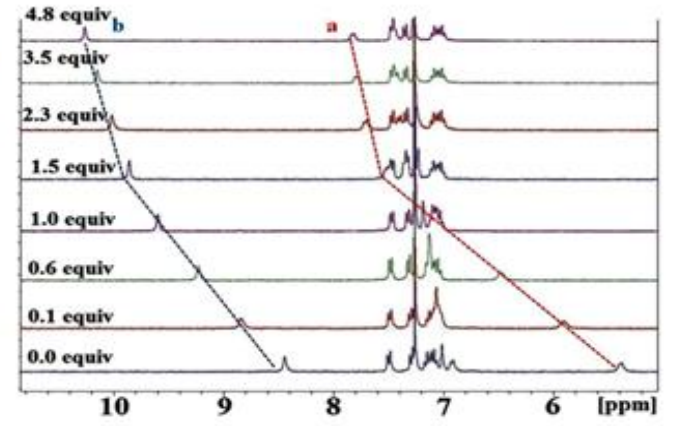

Figure 2. (a) UV-vis. titration profile for $4\left(2.1 \times 10^{-5} \mathrm{M}\right)$ with $\mathrm{CH}_{3} \mathrm{COO}^{-}\left(3.3 \times 10^{-2} \mathrm{M}\right)(0.0-216.0$ equiv) in $\mathrm{CHCl}_{3}$ (b) Partial ${ }^{1} \mathrm{H}$ NMR (300 MHz) titration profile for $4\left(4.6 \times 10^{-3} \mathrm{M}\right)$ with $\mathrm{CH}_{3} \mathrm{COO}^{-}(0.33 \mathrm{M})$ in $\mathrm{CDCl}_{3}$ (Temperature 296-298 K). 
indole NH showed a downfield shift of $1.78 \mathrm{ppm}$ (Table S1) indicating the binding of 4 to acetate. The amide protons did not take part in binding as evident from negligible changes in the chemical shift values upon addition of anion salt, this could be due steric hindrance by $\mathrm{Leu}-\mathrm{CH}_{3}$ groups. Compound 6 also surprisingly did not show considerable affinity towards anions which could be due to steric crowding around urea along with distantly placed Trp side chain.

Urea-triazole containing scaffold $\mathbf{1 0}$ shows highest affinity amongst all of the compounds tested. Compound 10 forms 1:1 complex with the anions (Figure S1). UV-vis. titration carried out with fluoride, biphosphate and bisulfate showed one isosbestic point at $300 \mathrm{~nm}$ (Figure 3, Figure $\mathrm{S} 2$ ). The binding constants (calculated by performing $1: 1$ non-linear fit analysis) ${ }^{28}$ for fluoride, biphosphate and bisulfate ions are reported in Table $1 .{ }^{1} \mathrm{H}$ NMR titration of $\mathbf{1 0}$ showed that upon slot-wise addition of $\mathrm{TBAH}_{2} \mathrm{PO}_{4}$ (Figure 3), the urea NHs shifted downfield ( $2.0 \mathrm{ppm}$ ) and amide $\mathrm{NH}$ shifted downfield by approximately $1.0 \mathrm{ppm}$. The triazole $\mathrm{CH}$ protons (c) showed a downfield shift of $\sim 0.80 \mathrm{ppm},{ }^{10,29-30}$ while aromatic protons showed a small downfield shift $(\sim 0.30 \mathrm{ppm})$. ${ }^{1} \mathrm{H}$ NMR titration of $\mathbf{1 0}$ with $\mathrm{TBAHSO}_{4}$ showed that the urea NHs and amide NHs shifted downfield by $\sim 0.80 \mathrm{ppm}$ and $\sim 0.35 \mathrm{ppm}, \quad$ respectively (Figure S3).

(a)

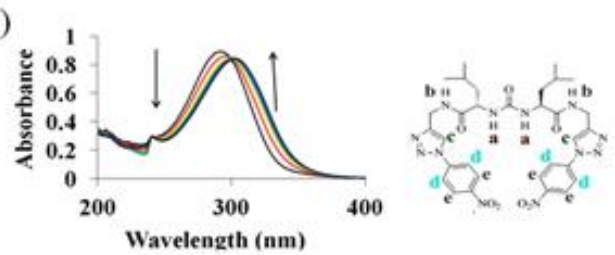

(b)

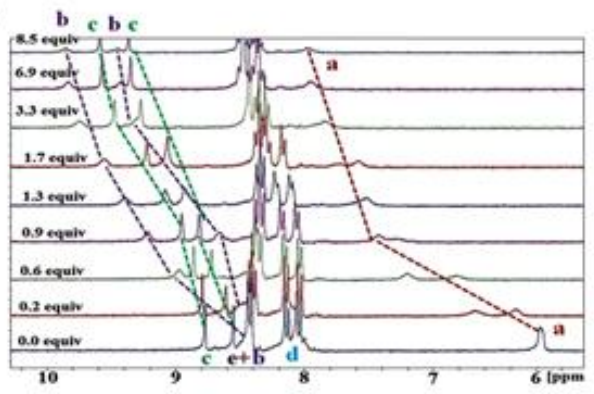

Figure 3. (a) UV-vis. titration profile for $10\left(4.3 \times 10^{-5} \mathrm{M}\right)$ with $\mathrm{H}_{2} \mathrm{PO}_{4}{ }^{-}\left(2.8 \times 10^{-2} \mathrm{M}\right)(0.0-9.5$ equiv) in acetone (b) Partial ${ }^{1} \mathrm{H}$ NMR $(300 \mathrm{MHz})$ titration profile for $\mathbf{1 0}\left(4.3 \times 10^{-5} \mathrm{M}\right)$ with $\mathrm{H}_{2} \mathrm{PO}_{4}{ }^{-}$ $\left(4.1 \times 10^{-1} \mathrm{M}\right)$ in acetone- $d_{6}$ (Temperature 296-298 K).

The triazole protons shifted downfield $(\sim 0.20 \mathrm{ppm})$, while the aromatic protons showed a slight downfield shift $(\sim 0.10 \mathrm{ppm})$ (Figure S3). The stronger binding of $\mathbf{1 0}$ towards anions as compared to other receptors can be correlated to its structure. The $p$-nitrophenyl group enhances the acidity of triazole $\mathrm{CH}$, which strengthens the hydrogen bonding. The less steric crowding around urea unit allows all NHs to take part in binding along with triazole CHs, hence increases the binding. Compound $\mathbf{1 0}$ also showed colorimetric response towards anions in acetone. The color change was monitored by adding 10.0 equiv. of TBA salts of anions to $4.34 \times 10^{-3} \mathrm{M}$ solution of 
$\mathbf{1 0}$ in acetone. A dark brown color was observed in the case of $\mathrm{F}^{-}$and $\mathrm{H}_{2} \mathrm{PO}_{4}{ }^{-}$(Figure 4). Thus, 10 acts as colorimetric sensor for anions and enable naked eye detection of anions. The binding constants of 2, 4, $\mathbf{6}$ and $\mathbf{1 0}$ are summarized in Table 1.

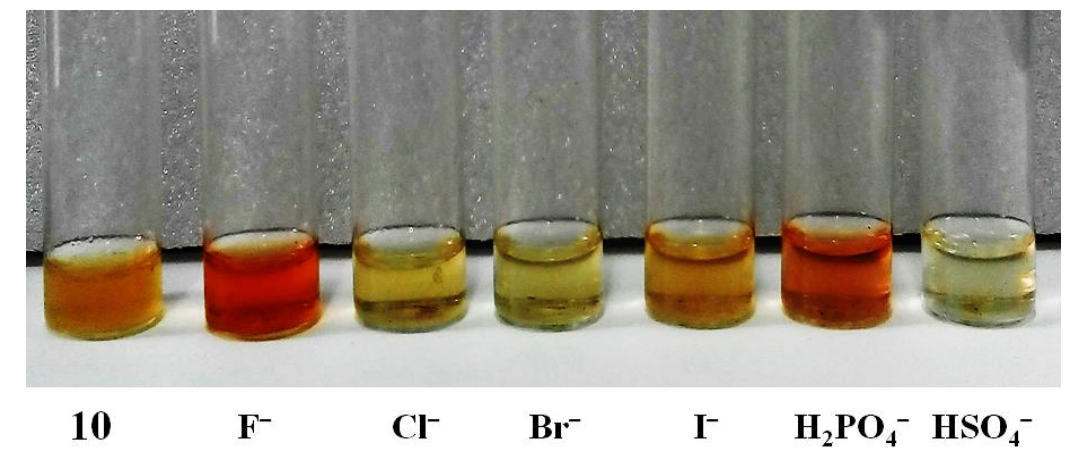

Figure 4. Images of vials showing colorimetric response of $\mathbf{1 0}\left(4.34 \times 10^{-3} \mathrm{M}\right)$ after addition of 10.0 equiv of TBA anions in acetone

Table 1. Binding constants for 2, 4, 6 and $\mathbf{1 0}$ with TBA anions calculated from UV-vis titrations.

\begin{tabular}{ccccc}
\hline \multicolumn{5}{c}{ Receptors } \\
\hline Anion & $\mathbf{2}$ & $\mathbf{4}$ & $\mathbf{6}$ & $\mathbf{1 0}$ \\
\hline $\mathrm{F}^{-}$ & $\mathrm{ND}$ & $\mathrm{ND}$ & $\mathrm{ND}$ & $50130.86 \pm 3.32 \%$ \\
$\mathrm{H}_{2} \mathrm{PO}_{4}{ }^{-}$ & $\mathrm{ND}$ & $\mathrm{ND}$ & $\mathrm{ND}$ & $653911.93 \pm 9.67 \%$ \\
$\mathrm{HSO}_{4}{ }^{-}$ & $\mathrm{ND}$ & $\mathrm{ND}$ & $\mathrm{ND}$ & $41912.44 \pm 2.54 \%$ \\
$\mathrm{CH}_{3} \mathrm{COO}^{-}$ & ND & $115.53 \pm 0.63 \%$ & ND & ND \\
\hline
\end{tabular}

ND: not determined

\section{Self-assembly studies}

Compounds 2, 4, 6 and 10 contain amino acid as well as urea linkage, hence possess excellent capability for self-assembly. Therefore, self-assembling features of $\mathbf{2 , 4 , 6}$ and $\mathbf{1 0}$ were studied by using several microscopic techniques. Scanning electron microscopic (SEM) images of 2, 4, 6 and 10 in 1:1 $\mathrm{CH}_{3} \mathrm{OH} / \mathrm{CHCl}_{3}$ showed vesicular morphology (Figure 5). The morphological features of 2, 4, 6 and 10 were also confirmed by transmission electron microscopy (TEM) (stained with 0.2 $\%$ phosphotungstic acid) and atomic force microscopy (AFM) (tapping mode) (Figure S4). 

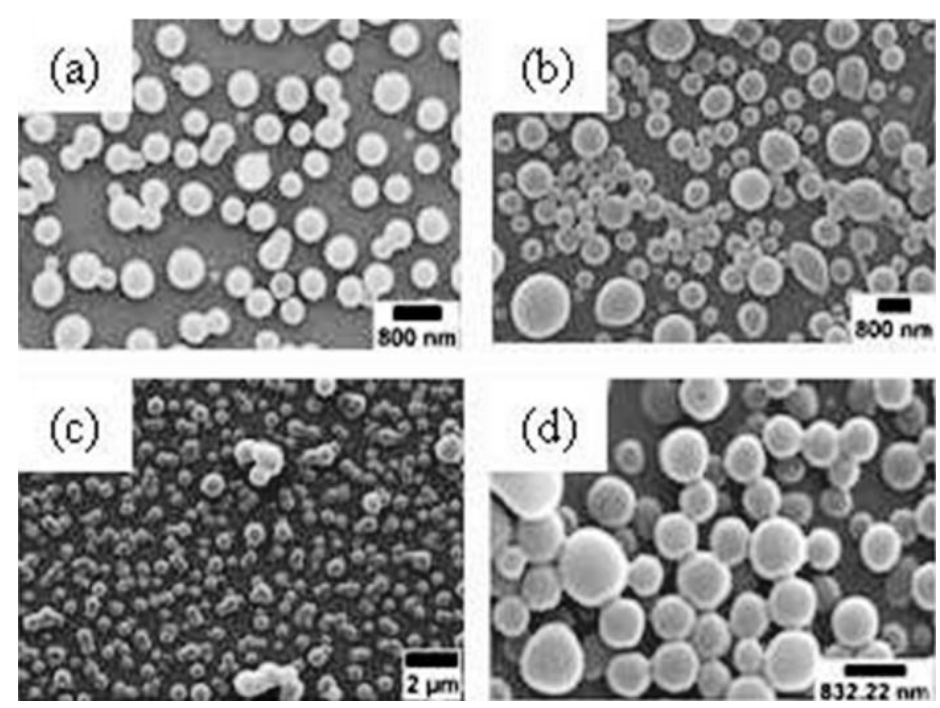

Figure 5. SEM images of (a) $\mathbf{2}(3.2 \mathrm{mM})$ (b) $\mathbf{4}(2.9 \mathrm{mM})$ (c) $\mathbf{6}(2.8 \mathrm{mM})(\mathrm{d}) \mathbf{1 0}(2.8 \mathrm{mM})$ in $1: 1$ $\mathrm{CH}_{3} \mathrm{OH} / \mathrm{CHCl}_{3}$ respectively.

Even though, there is a high propensity for urea-based molecules to form fibrous or sheet-like morphology, yet it is surprising to observe that 2, 4, 6 and $\mathbf{1 0}$ formed vesicles. It is noteworthy that $\mathbf{1}$ (precursor of 2) shows fiber-like morphology, while $\mathbf{3}$ and $\mathbf{5}$ (precursors of $\mathbf{4}$ and $\mathbf{6}$ respectively) formed vesicles (Figure S5). Compound 1 contains lesser number of amide bonds and aromatic rings, compared to $\mathbf{2 , 4 , 6}$ and $\mathbf{1 0}$. This might be the reason for fibrous morphology of $\mathbf{1}$. Therefore, it shows the importance of number of amide bonds as well as aromatic rings in the molecule. Compounds $\mathbf{8}$ and $\mathbf{9}$, which are precursors of $\mathbf{1 0}$, formed fibrous morphology (Figure S5), thus underlining the importance of triazole and aromatic rings present in $\mathbf{1 0}$ to give vesicular structure. Aromatic rings may facilitate $\pi-\pi$ stacking, while urea and amide NHs can form hydrogen bonding which results in this vesicular morphology. The size of vesicles obtained from microscopic studies range from 0.3-1.3 $\mu \mathrm{m}$ (Figure S6). This size approximately matches with the size obtained from dynamic light scattering (DLS) measurements (Figure S7). The DLS studies show the size of the vesicles ranges from $0.3-0.8 \mu \mathrm{m}$.

The effect of addition of anions on vesicles of $\mathbf{1 0}$ was studied by SEM and DLS. Addition of 5.0 equiv. of TBA anions (biphosphate/bisulfate) to a solution of $\mathbf{1 0}$ (Figure 6) resulted in the formation of flattened vesicles with increased size. Addition of biphosphate salt resulted in the formation of pores on the surface of vesicles (Figure 6). The increase in the average size of vesicles upon addition of 5.0 equiv. of anion salt is also supported by DLS studies (Figure S7). The increase in the size upon addition of anions is attributed to the binding of molecules to anions. ${ }^{8,31-32}$ The presence of vesicular structure even after addition of 5.0 equiv. of anion salt demonstrates the robust nature of the vesicles. 

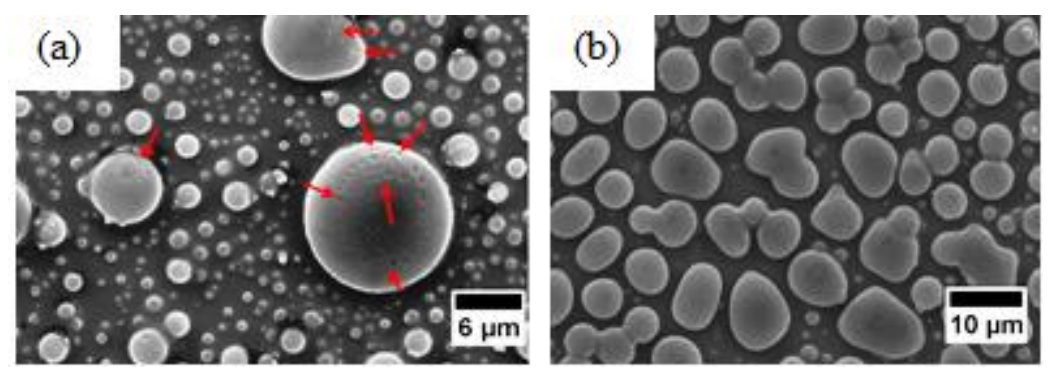

Figure 6. SEM images of (a) $\mathbf{1 0}+5.0$ equiv. $\mathrm{H}_{2} \mathrm{PO}_{4}{ }^{-}$(arrows show position of small pores on the surface of vesicles) (b) $\mathbf{1 0}+5.0$ equiv. $\mathrm{HSO}_{4}{ }^{-}$in $1: 1 \mathrm{CH}_{3} \mathrm{OH} / \mathrm{CHCl}_{3}$ respectively.

\section{Conclusions}

In summary, we have designed and synthesized urea functionalized peptides $\mathbf{2 , 4 , 6}$ and $\mathbf{1 0}$. The binding property of these peptides towards tetrabutylammonium salts of different anions was analyzed in detail. It was found that urea-cored compounds $\mathbf{4}$ and $\mathbf{6}$ have very weak affinity, while urea-triazole containing $\mathbf{1 0}$ turned out to be the most efficient receptor. Compound $\mathbf{1 0}$ acts as a colorimetric sensor for fluoride and biphosphate. The self-assembling studies on these urea-cored and urea-triazole containing peptides revealed that 2, 4, 6 and 10 self-assembled into vesicles. Addition of anions to the self-assembled vesicles of $\mathbf{1 0}$ resulted in the change of vesicles size. The unison of Trp or triazole with urea enabled strong bias towards vesicular self-assembly. Incorporation of triazole improved the anion binding ability of the urea-cored amino acid appended molecule. These findings will help in the design of new generation of self-assembling and anion binding molecules.

\section{Experimental Section}

\section{General information}

All organic solvents employed in the synthesis were distilled and dried using appropriate drying agents. Reactions were monitored by silica gel-based thin layer chromatography (TLC). Silica gel (100-200 mesh) was used for purification by column chromatography. A Fisher-Scientific apparatus was used for recording melting points. FT-IR spectra were measured using a Nicolet Protégé 460 spectrometer using KBr pellets. ${ }^{1} \mathrm{H}$ NMR spectra were recorded on Brucker-DPX-300 spectrometer. Tetramethylsilane $\left({ }^{1} \mathrm{H}\right)$ was used as an internal standard. Coupling constants are reported in $\mathrm{Hz}$ and data are reported as s (singlet), d (doublet), br (broad), t (triplet), dd (double doublet) and $\mathrm{m}$ (multiplet). High resolution mass spectra (HRMS) were recorded in Bruker MicrOTOF-QII model using ESI technique. UV-visible spectra were recorded in Shimadzu double beam spectrophotometer, UV-2450. 


\section{Synthetic procedures}

Synthesis of compound 3. To Z-Leucine-OH ( $\mathrm{Z}$ = benzyloxycarbonyl, an amine-protecting group) $(0.2 \mathrm{~g}, 0.75 \mathrm{mmol})$ in dry $\mathrm{CH}_{2} \mathrm{Cl}_{2}$ at $0{ }^{\circ} \mathrm{C}$, added $0.5 \mathrm{~mL}$ dimethylformamide (DMF) followed by $N$-hydroxysuccinimide $(\mathrm{HOSu}) \quad(0.11 \mathrm{~g}, \quad 0.91 \mathrm{mmol})$ and $N, N^{\prime}-$ dicyclohexylcarbodiimide (DCC) $(0.19 \mathrm{~g}, 0.91 \mathrm{mmol})$. To this was added a solution of L-TrpOMe. $\mathrm{HCl}(0.23 \mathrm{~g}, 0.91 \mathrm{mmol})$ in dry $\mathrm{CH}_{2} \mathrm{Cl}_{2}$ and $\mathrm{NEt}_{3}(0.13 \mathrm{~mL}, 0.91 \mathrm{mmol})$. The reaction mixture was stirred for $24 \mathrm{~h}$. The organic layer was washed sequentially with $0.2 \mathrm{~N} \mathrm{H}_{2} \mathrm{SO}_{4}$, sat. solution of $\mathrm{NaHCO}_{3}$ and distilled water followed by drying on anhyd. $\mathrm{Na}_{2} \mathrm{SO}_{4}$. Then it was concentrated to give crude compound. The crude compound was purified by column chromatography using ethyl acetate-hexane as eluents to give 3 as white solid (59\%). Mp: 57-60 ${ }^{\circ} \mathrm{C} .{ }^{1} \mathrm{H}$ NMR (300 MHz, $\left.\mathrm{CDCl}_{3}\right): \delta 0.89$ (br s*, 6H, Leu $\left.\left(\mathrm{C}_{3}\right)_{2}\right), 1.34\left(\mathrm{~m}, 3 \mathrm{H}\right.$, Leu $\left(\mathrm{C} \underline{\mathrm{H}}+\mathrm{C}_{2}\right)$ ), 3.06 (br d, $2 \mathrm{H}, J 3.0 \mathrm{~Hz}$, $\left.\operatorname{Trp}(\mathrm{C} \underline{\mathrm{H}})_{2}\right), 3.43\left(\mathrm{~s}, 3 \mathrm{H},-\mathrm{OC} \underline{H}_{3}\right), 4.02(\mathrm{~m}, 1 \mathrm{H}, \alpha-\mathrm{C} \underline{\mathrm{H}}), 4.67(\mathrm{~m}, 1 \mathrm{H}, \alpha-\mathrm{C} \underline{\mathrm{H}}), 4.81(\mathrm{~m}, 2 \mathrm{H}$, Phe $\left.\left(\mathrm{C}_{2}\right)\right), 5.01(\mathrm{~d}, 1 \mathrm{H}, J 9.0 \mathrm{~Hz}, \mathrm{~N} \underline{\mathrm{H}}), 6.45(\mathrm{~d}, 1 \mathrm{H}, J 6.6 \mathrm{~Hz}, \mathrm{~N} \underline{\mathrm{H}}), 6.72(\mathrm{~s}, 1 \mathrm{H}, \operatorname{Ar} \underline{\mathrm{H}}), 6.89(\mathrm{~m}, 2 \mathrm{H}$, $\operatorname{Ar} \underline{\mathrm{H}}), 7.07(\mathrm{~m}, 6 \mathrm{H}, \operatorname{Ar} \underline{\mathrm{H}}), 7.27$ (d, 1H, J 7.5 Hz, Ar$\underline{\mathrm{H}}), 7.95$ (br s, $1 \mathrm{H}$, indole $\mathrm{N} \underline{\mathrm{H}}) .{ }^{13} \mathrm{C}$ NMR $(75$ $\left.\mathrm{MHz}, \mathrm{CDCl}_{3}\right): \delta 22.85,24.92,27.50,33.94,41.44,49.18,52.36,52.79,53.55,66.97,109.68$, 111.23, 118.50, 119.65, 122.22, 123.05, 127.52, 128.03, 128.19, 128.55, 136.05, 156.03, 171.68, 171.96. IR (KBr):1053, 1204, 1357, 1444, 1526, 1640, 1727, 2930, 3068, 3327, $3397 \mathrm{~cm}^{-1}$. HRMS calcd for $\mathrm{C}_{26} \mathrm{H}_{31} \mathrm{~N}_{3} \mathrm{O}_{5} \mathrm{Na} / z / 288.2155$ found 488.2154 .

Synthesis of compound 5. To Z-Tryptophan- $\mathrm{OH}(\mathrm{Z}=$ benzyloxycarbonyl $)(0.5 \mathrm{~g}, 1.47 \mathrm{mmol})$ in dry $\mathrm{CH}_{2} \mathrm{Cl}_{2}$ at $0{ }^{\circ} \mathrm{C}$, added $0.5 \mathrm{~mL} \mathrm{DMF}$ followed by HOSu $(0.20 \mathrm{~g}, 1.76 \mathrm{mmol})$ and DCC $(0.36 \mathrm{~g}$, $1.76 \mathrm{mmol})$. To this was added solution of L-leu-OMe. $\mathrm{HCl}(0.32 \mathrm{~g}, 1.76 \mathrm{mmol})$ in dry $\mathrm{CH}_{2} \mathrm{Cl}_{2}$ and $\mathrm{NEt}_{3}(0.25 \mathrm{~mL}, 1.76 \mathrm{mmol})$. The reaction mixture was stirred for $24 \mathrm{~h}$. The organic layer was washed sequentially with $0.2 \mathrm{~N} \mathrm{H}_{2} \mathrm{SO}_{4}$, sat. solution of $\mathrm{NaHCO}_{3}$ and distilled water followed by drying on anhyd. $\mathrm{Na}_{2} \mathrm{SO}_{4}$. Then it was concentrated to give crude compound. The crude compound was purified by column chromatography using ethyl acetate-hexane as eluents to give $\mathbf{5}$ as white solid (46\%). Mp: 55-57 ${ }^{\circ} \mathrm{C} .{ }^{1} \mathrm{H}$ NMR (300 MHz, $\left.\mathrm{CDCl}_{3}\right): \delta 0.85$ (br s*, 6H, Leu $\left.\left(\mathrm{C}_{3}\right)_{2}\right), 1.46(\mathrm{~m}$, $3 \mathrm{H}$, Leu $\left.\left(\mathrm{C} \underline{\mathrm{H}}+\underline{\mathrm{C}}_{2}\right)\right), 3.22\left(\mathrm{~m}, 2 \mathrm{H}, \operatorname{Trp}(\mathrm{C} \underline{\mathrm{H}})_{2}\right), 3.64\left(\mathrm{~s}, 3 \mathrm{H},-\mathrm{OC}_{3}\right), 4.52(\mathrm{~m}, 2 \mathrm{H}, \alpha-\mathrm{C} \underline{\mathrm{H}}), 4.95$ (s, 2H, Phe $\left.\left(\mathrm{C}_{2}\right)\right), 5.55(\mathrm{~d}, 1 \mathrm{H}, J 6.0 \mathrm{~Hz}, \mathrm{~N} \underline{\mathrm{H}}), 7.19(\mathrm{~m}, 10 \mathrm{H}, \operatorname{Ar} \underline{\mathrm{H}}), 7.69(\mathrm{~d}, 1 \mathrm{H}, J 6.0 \mathrm{~Hz}, \mathrm{~N} \underline{\mathrm{H}})$, 8.25 (br s, $1 \mathrm{H}$, indole $\mathrm{NH}) .{ }^{13} \mathrm{C}$ NMR $\left(75 \mathrm{MHz}, \mathrm{CDCl}_{3}\right): \delta 21.86,22.55,24.72,27.29,41.38,50.80$, 52.15, 55.41, 66.97, 110.23, 111.17, 118.76, 119.71, 122.16, 123.46, 127.31, 128.04, 128.47, 136.20, 155.95, 171.00, 172.78. IR (KBr):1051, 1224, 1345, 1447, 1536, 1663, 1730, 2953, 3062, $3312,3388 \mathrm{~cm}^{-1}$. HRMS calcd for $\mathrm{C}_{26} \mathrm{H}_{31} \mathrm{~N}_{3} \mathrm{O}_{5} \mathrm{Na} \mathrm{m} / 2488.2156$ found 488.2162 .

General procedure for synthesis of compounds $2,4,6$. To the amino acid methyl ester $(0.21 \mathrm{~g}$, $0.64 \mathrm{mmol})$ in dry $\mathrm{CH}_{2} \mathrm{Cl}_{2}$ and $\mathrm{NEt}_{3}(0.08 \mathrm{~mL}, 0.16 \mathrm{mmol})$ at $60-70{ }^{\circ} \mathrm{C}$, phosgene $(0.07 \mathrm{~mL}, 0.64$ $\mathrm{mmol}$ ) in dry $\mathrm{CH}_{2} \mathrm{Cl}_{2}$ was added dropwise. The reaction mixture was refluxed with constant stirring for $12 \mathrm{~h}$. The organic layer was washed with $0.2 \mathrm{~N} \mathrm{H}_{2} \mathrm{SO}_{4}$, sat. $\mathrm{NaHCO}_{3}$ and distilled water. Organic layer was dried over anhyd. $\mathrm{Na}_{2} \mathrm{SO}_{4}$, evaporated and weighed to give crude compound. The crude compound was purified by column chromatography using ethyl acetate-hexane as eluents to give desired pure urea-based compound. 
Data of 2. Appearance: Off-white solid. Yield: $88 \%$. Mp: 131-133 ${ }^{\circ} \mathrm{C} .{ }^{1} \mathrm{H}$ NMR $(300 \mathrm{MHz}$,

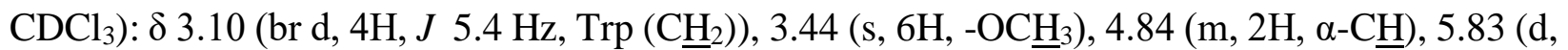
$2 \mathrm{H}, J 8.4 \mathrm{~Hz}, \underline{\mathrm{H}}), 6.74(\mathrm{~m}, 2 \mathrm{H}, \operatorname{Ar} \underline{\mathrm{H}}), 7.10$ (m, 4H, Ar$\underline{\mathrm{H}}), 7.30$ (d, 2H, J 9.3 Hz, ArH $), 7.45$ (d, $2 \mathrm{H}, J 7.8 \mathrm{~Hz}, \mathrm{Ar} \underline{\mathrm{H}}), 8.37$ (br s, $2 \mathrm{H}$, indole $(\mathrm{N} \underline{\mathrm{H}})$ ). ${ }^{13} \mathrm{C} \mathrm{NMR}\left(75 \mathrm{MHz}, \mathrm{CDCl}_{3}\right): \delta 28.05,52.21$, 53.10, 109.41, 111.24, 118.43, 119.33, 121.87, 123.38, 127.43, 135.94, 157.03, 173.88.

IR (KBr): 1015, 1104, 1213, 1351, 1440, 1554, 1651, 1734, 2854, 2924, $3397 \mathrm{~cm}^{-1}$. HRMS calcd for $\mathrm{C}_{25} \mathrm{H}_{26} \mathrm{~N}_{4} \mathrm{O}_{5} \mathrm{Na} m / z, 485.1795$ found 485.1794 .

Data of 4. Appearance: White solid. Yield: $56 \%$. Mp: 65-67 ${ }^{\circ} \mathrm{C} .{ }^{1} \mathrm{H}$ NMR $\left(300 \mathrm{MHz}, \mathrm{CDCl}_{3}\right): \delta$ 0.83 (br s*, 12H, Leu $\left.\left(\mathrm{C}_{3}\right)_{2}\right), 1.44\left(\mathrm{~m}, 6 \mathrm{H}\right.$, Leu $\left.\left(\mathrm{CH}+\underline{\mathrm{C}}_{2}\right)\right), 3.20$ (dd, 4H, $J_{1} 22.2 \mathrm{~Hz}, J_{2} 10.5$

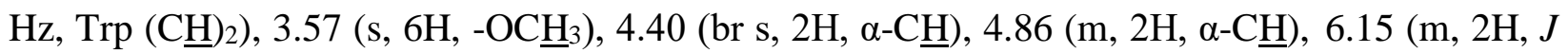
$24 \mathrm{~Hz}, \mathrm{~N} \underline{\mathrm{H}}), 7.12(\mathrm{~m}, 10 \mathrm{H}, 8 \mathrm{Ar} \underline{\mathrm{H}}+2 \mathrm{~N} \underline{\mathrm{H}}), 7.47$ (d, 2H, J 7.5 Hz, ArH $), 8.59$ (br s, 2H, indole $(\mathrm{NH})) .{ }^{13} \mathrm{C} \mathrm{NMR}\left(75 \mathrm{MHz}, \mathrm{CDCl}_{3}\right): \delta 21.90,22.74,24.64,27.29,41.68,52.29,52.73,108.97$, 109.27, 111.37, 111.64, 118.28, 119.25, 121.79, 122.07, 123.73, 127.31, 136.00, 158.14, 172.21, 173.72. IR (KBr):1101, 1213, 1361, 1440, 1547, 1640, 1740, 2955, $3388 \mathrm{~cm}^{-1}$. HRMS calcd for $\mathrm{C}_{37} \mathrm{H}_{48} \mathrm{~N}_{6} \mathrm{O}_{7} \mathrm{Na} m / z 711.3477$ found 711.3483 .

Data of 6. Appearance: Off-white solid. Yield: $44 \%$. Mp: 67-70 ${ }^{\circ} \mathrm{C} .{ }^{1} \mathrm{H} \mathrm{NMR}\left(300 \mathrm{MHz}, \mathrm{CDCl}_{3}\right)$ : $\delta 0.84$ (br s*, 12H, Leu $\left.\left(\mathrm{C}_{3}\right)_{2}\right), 1.48\left(\mathrm{~m}, 6 \mathrm{H}, \mathrm{Leu}\left(\mathrm{CH}+\underline{\mathrm{C}}_{2}\right)\right), 3.15\left(\mathrm{~m}, 4 \mathrm{H}, \operatorname{Trp}(\mathrm{CH})_{2}\right), 3.57(\mathrm{~s}$, $\left.6 \mathrm{H},-\mathrm{OC} \underline{\mathrm{H}}_{3}\right), 4.36(\mathrm{~m}, 2 \mathrm{H}, \alpha-\mathrm{CH}), 4.74(\mathrm{~m}, 2 \mathrm{H}, \alpha-\mathrm{CH}), 6.31(\mathrm{~d}, 2 \mathrm{H}, J 6.6 \mathrm{~Hz}, \mathrm{~N} \underline{\mathrm{H}}), 7.23(\mathrm{~m}, 10 \mathrm{H}$, $\operatorname{Ar} \underline{\mathrm{H}}), 8.10$ (br s, $2 \mathrm{H}, \mathrm{N} \underline{\mathrm{H}}), 8.20(\mathrm{~d}, 2 \mathrm{H}, J 7.8 \mathrm{~Hz}$, indole $\mathrm{N} \underline{\mathrm{H}}) \cdot{ }^{13} \mathrm{C} \mathrm{NMR}\left(75 \mathrm{MHz}, \mathrm{CDCl}_{3}\right): \delta$ 21.90, 22.74, 24.64, 27.29, 41.68, 52.29, 52.73, 108.97, 109.27, 111.37, 111.64, 118.28, 119.25, $121.79,122.07,123.73,127.31,136.00,158.14,172.21,173.72$. IR (KBr):1210, 1447, 1655, 1739, 2934, 3388, $3411 \mathrm{~cm}^{-1}$. HRMS calcd for $\mathrm{C}_{37} \mathrm{H}_{48} \mathrm{~N}_{6} \mathrm{O}_{7} \mathrm{Na} m / z, 711.3477$ found 711.3477 .

Synthesis of compound 9. Compound $8(0.23 \mathrm{~g}, 0.73 \mathrm{mmol})$ in $\mathrm{CH}_{3} \mathrm{OH}(4.0 \mathrm{~mL})$ was hydrolysed using $4 \mathrm{~N} \mathrm{NaOH}(4.0 \mathrm{~mL})$ at $0-4{ }^{\circ} \mathrm{C}$ to give diacid $(0.2 \mathrm{~g}, 0.69 \mathrm{mmol})$. To the diacid $(0.2 \mathrm{~g}, 0.69$ $\mathrm{mmol})$ in dry $\mathrm{CH}_{2} \mathrm{Cl}_{2}$ at $0-4{ }^{\circ} \mathrm{C}$, was admixed, $\mathrm{HOSu}(0.175 \mathrm{~g}, 1.52 \mathrm{mmoL})$ and DCC $(0.31 \mathrm{~g}, 1.52$ $\mathrm{mmol})$ sequentially followed by propargyl amine $(0.1 \mathrm{~mL}, 1.52 \mathrm{mmol})$. The reaction mixture was stirred for $24 \mathrm{~h}$. The organic layer was washed sequentially with $0.2 \mathrm{~N} \mathrm{H}_{2} \mathrm{SO}_{4}$, sat. solution of $\mathrm{NaHCO}_{3}$ and distilled water followed by drying on anhyd. $\mathrm{Na}_{2} \mathrm{SO}_{4}$. Then it was concentrated to give crude compound. The crude compound was chromatographed on a column of silica gel by using ethylacetate-hexane as eluents to give pure 9 white solid (79.5\%). Mp: $123-125{ }^{\circ} \mathrm{C} .{ }^{1} \mathrm{H} \mathrm{NMR}$ $\left(300 \mathrm{MHz}, \mathrm{CDCl}_{3}\right): \delta 0.86$ (br s*, 12H, Leu $\left.\left(\mathrm{C}_{3}\right)_{2}\right), 1.51\left(\mathrm{~m}, 6 \mathrm{H}, \mathrm{Leu}\left(\mathrm{C} \underline{\mathrm{H}}+\mathrm{CH}_{2}\right)\right), 2.28(\mathrm{~s}, 2 \mathrm{H}$, alkyne $\mathrm{C} \underline{\mathrm{H}}), 3.97$ (dd, $\left.J_{1} 17.1 \mathrm{~Hz}, J_{2} 5.4 \mathrm{~Hz}, 4 \mathrm{H}, \mathrm{NH}\left(\mathrm{C}_{2}\right)\right), 4.45$ (m, 2H, $\left.\alpha-\mathrm{C} \underline{\mathrm{H}}\right), 6.34$ (d, 2H, $J$ $4.5 \mathrm{~Hz}, \mathrm{~N} \underline{\mathrm{H}}$ ), 7.76 (br s, $1 \mathrm{H}, \mathrm{N} \underline{\mathrm{H}}), 7.84$ (br s, $1 \mathrm{H}, \mathrm{N} \underline{\mathrm{H}}) .{ }^{13} \mathrm{C} \mathrm{NMR}\left(75 \mathrm{MHz}, \mathrm{CDCl}_{3}\right.$ ): $\delta$ 24.58, 25.57, 29.09, 33.89, 41.96, 49.18, 52.15, 71.35, 79.44, 156.74, 157.85, 173.70. IR (KBr):1227, 1443, $1561,1625,2853,2929,3281,3381 \mathrm{~cm}^{-1}$. HRMS calcd for $\mathrm{C}_{19} \mathrm{H}_{30} \mathrm{~N}_{4} \mathrm{O}_{3} \mathrm{Na} / z, 385.2210$ found 385.2210 .

Synthesis of compound 10. To the compound $9(0.19 \mathrm{~g}, 0.54 \mathrm{mmol})$ in acetonitrile at $0{ }^{\circ} \mathrm{C}$, was added DIPEA $(0.38 \mathrm{~mL}, 1.18 \mathrm{mmol})$ followed by 4-nitrophenylazide $(0.19 \mathrm{~g}, 1.18 \mathrm{mmol})$ in $\mathrm{CH}_{3} \mathrm{CN}$. To this reaction mixture was added $\mathrm{CuI}(0.020 \mathrm{~g}, 0.11 \mathrm{mmol})$ followed by stirring for 24 $\mathrm{h}$ under argon atmosphere. Reaction mixture was filtered and the filtrate was evaporated. The 
residue obtained from evaporation of filtrate was insoluble in chloroform, ethyl acetate and dichloroform. Therefore, the residue was directly washed with 9:1 $\mathrm{NH}_{4} \mathrm{Cl} / \mathrm{NH}_{4} \mathrm{OH}$ solution (50 $\mathrm{mLx} 3)$ and distilled water $(50 \mathrm{~mL} \times 3)$ to give crude $\mathbf{1 0}$. The crude product was purified by column chromatography with methanol-chloroform as eluents to give $\mathbf{1 0}$ as light yellow solid (89 \%). Mp: 135-137 ${ }^{\circ} \mathrm{C} .{ }^{1} \mathrm{H}$ NMR (300 MHz, Acetone- $\left.d_{6}\right): \delta 0.87\left(\mathrm{~m}, 12 \mathrm{H}\right.$, Leu $\left.\left(\mathrm{C}_{3}\right)_{2}\right), 1.65(\mathrm{~m}, 6 \mathrm{H}, \mathrm{Leu}(\mathrm{C} \underline{\mathrm{H}}$

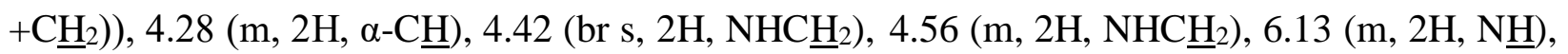
$8.07(\mathrm{~m}, 6 \mathrm{H}, 4 \mathrm{Ar} \underline{\mathrm{H}}+2 \mathrm{~N} \underline{\mathrm{H}}), 8.41(\mathrm{~d}, 4 \mathrm{H}, J 8.7 \mathrm{~Hz}, \mathrm{Ar} \underline{\mathrm{H}}), 8.55$ (br s, 1H, triazole-Cㅂ) $), 8.75$ (br s, $1 \mathrm{H}$, triazole-C $\underline{\mathrm{H}}) .{ }^{13} \mathrm{C}$ NMR $\left(75 \mathrm{MHz}\right.$, Acetone- $\left.d_{6}\right): \delta 22.01,23.41,26.00,35.56,42.17,54.13$, $120.88,121.78,126.30,132.21,142.07,147.78,159.35,174.75$. IR (KBr):1046, 1256, 1344, 1525, 1642, 2953, $3301 \mathrm{~cm}^{-1}$. HRMS calcd for $\mathrm{C}_{31} \mathrm{H}_{38} \mathrm{~N}_{12} \mathrm{O}_{7} \mathrm{Na} m / z, 713.2879$ found 713.2868 .

* br s = broad singlet

\section{UV-vis titration experiments}

Stock solutions of compounds 2, 4, 6 and 10 were prepared in spectroscopy grade chloroform with concentration $\left(10^{-4}-10^{-5} \mathrm{M}\right)$. Solutions of anion salts were prepared in chloroform with concentration $\left(10^{-1}-10^{-2} \mathrm{M}\right)$. The absorbance of blank compound solution and solution after gradual addition of anion salt were recorded using Shimadzu double beam UV-vis. spectrophotometer model UV-2450.

\section{NMR titration experiments}

Stock solutions of compounds 2, 4, 6 and 10 were prepared in $\mathrm{CDCl}_{3}$ with concentration $10^{-3} \mathrm{M}$. Solutions of anion salts were prepared in $\mathrm{CDCl}_{3}$ with concentration $10^{-1} \mathrm{M}$. The spectra were collected on a Bruker DRX 300 (300 MHz) NMR spectrometer. Anion binding titrations were carried out by monitoring changes in the aromatic proton $(\mathrm{Ar} H)$, amide $\mathrm{NH}$ and triazole $\mathrm{CH}$ signal of receptors as a function of added halide salt concentration.

\section{Calculation of binding constants and stoichiometry}

The binding constants were calculated by a non-linear fitting using Bindfit (http://www.supramolecular.org). UV fitting for 1:1 model was done using the Nelder-Mead method. Stoichiometry of binding was calculated by Job plot from UV-vis. absorbance data.

\section{Microscopy methods}

Optical microscopy: A drop of solution of the compound was put on a glass slide, the solvent was allowed to evaporate in air. It was then viewed using Nikon Eclipse TS100 optical microscope system.

Transmission electron microscopy: Around $3.0 \mathrm{mM}$ solution of the sample in methanolchloroform (1:1) was used for TEM. All the sample solutions were filtered through a nylon syringe filter $(0.2 \mu \mathrm{m})$. About $2 \mu \mathrm{l}$ aliquot of the sample solution was placed on a 200 mesh copper grid and stained with $0.2 \% \mathrm{wt}$. phosphotungstic acid in water for $2 \mathrm{~min}$. and the grid was allowed to dry in atmosphere. Samples were viewed using a Philips CM 12 transmission electron microscope. Scanning electron microscopy: Around 3.0-4.0 mM solution of compound in 1:1 methanolchloroform was prepared and one drop of the solution was put on the glass cover slip pasted on a carbon tape mounted on a stub, dried under sodium lamp and coated with $\sim 10 \mathrm{~nm}$ of gold. Samples were analyzed using scanning electron microscope ZEISS EVO 50 SEM. 
Atomic force microscopy: Around 3.0-4.0 mM solution of compound in 1:1 methanol-chloroform was prepared and one drop of the solution was put on silicon wafer and dried in atmosphere. Samples were analyzed using Dimension Icon AFM operating at tapping mode in air. Images were recorded in air at room temperature and data analysis was performed using nanoscope 5.31r software.

\section{Acknowledgements}

We thank DST [Grant No. SB/S1/OC-23/2014], New Delhi for financial assistance. We acknowledge the Department of Textile Engineering, IITD for SEM images. IB and RS thanks CSIR, New Delhi for the fellowship.

\section{Supplemental material}

${ }^{1} \mathrm{H}$ NMR, ${ }^{13} \mathrm{C}$ NMR, HRMS spectral data, UV-vis. data and microscopic images are available in the supplementary material provided with this manuscript.

\section{References}

1. Bowman-James, K.; Bianchi, A.; Garcìa-Espana, E. Anion Coordination Chemistry, WileyInterscience, Eds. 2012, 560 pp.

2. Caltagirone, C.; Gale, P. A. Chem. Soc. Rev. 2009, 38, 520-563. http://pubs.rsc.org/en/content/articlepdf/2009/cs/b806422a

3. Gale, P. A.; Garcia-Garrido, S. E.; Garric, J. Chem. Soc. Rev. 2008, 37, 151-190. http://pubs.rsc.org/en/content/articlepdf/2008/cs/b715825d

4. Gale, P. A. Acc. Chem. Res. 2006, 39, 465-475. http://pubs.acs.org/doi/pdf/10.1021/ar040237q

5. Gale, P. A.; Quesada, R. Coord. Chem. Rev. 2006, 250, 3219-3244. http://www.sciencedirect.com/science/article/pii/S0010854506001780

6. Gunnlaugsson, T.; Glynn, M.; Tocci, G. M.; Kruger, P. E.; Pfeffer, F.M. Coord. Chem. Rev. 2006, 250, 3094-3117. http://www.sciencedirect.com/science/article/pii/S0010854506002591

7. Amendola, V.; Bonizzoni, M.; Esteban-Gomez, D.; Fabbrizzi, L.; Licchelli, L.; Sancenn, F.; Taglietti, A. Coord. Chem. Rev. 2006, 250, 1451-1470. http://www.sciencedirect.com/science/article/pii/S0010854506000063

8. Bhardwaj, I.; Haridas, V. Tetrahedron 2016, 72, 2900-2905. http://www.sciencedirect.com/science/article/pii/S0040402016302563 
9. Haridas, V.; Sahu, S.; Venugopalan, P. Tetrahedron 2011, 67, 727-733. http://www.sciencedirect.com/science/article/pii/S0040402010017540

10. Haridas, V.; Sahu, S.; Praveen Kumar, P. P. Tetrahedron Lett. 2011, 52, 6930-6934. http://www.sciencedirect.com/science/article/pii/S0040403911017953

11. Smith, P. J.; Reddington, M. V.; Wilcox, C. S. Tetrahedron Lett. 1992, 33, 6085-6088. http://www.sciencedirect.com/science/article/pii/S0040403900600126

12. Fan, E.; Van Arman, S. E.; Kincaid, S.; Hamilton, A. D. J. Am.Chem. Soc. 1993, 115, 369370. http://pubs.acs.org/doi/abs/10.1021/ja00054a066

13. Dydio, P.; Lichosyt, D.; Jurczak, J. Chem. Soc. Rev. 2011, 40, 2971-2985. http://pubs.rsc.org/en/content/articlepdf/2011/cs/c1cs15006e

14. Ghosh, K.; Saha, I.; Masanta, G.; Wang, E. B.; Parish, C. A. Tetrahedron Lett. 2010, 51, $343-$ 347. http://www.sciencedirect.com/science/article/pii/S0040403909021418

15. Li, A. F.; Wang, J. H.; Wang, F.; Jiang, Y. B. Chem. Soc. Rev. 2010, 39, 3729-3745. http://pubs.rsc.org/en/content/articlepdf/2010/cs/b926160p

16. Amendola, V.; Fabbrizzi, L.; Mosca, L. Chem. Soc. Rev. 2010, 39, 3889-3915. http://pubs.rsc.org/en/content/articlepdf/2010/cs/b822552b

17. Haridas, V.; Sadanandan, S.; Hundal, G.; Suresh, C. H. Tetrahedron Lett. 2012, 53, 5523-5527. http://www.sciencedirect.com/science/article/pii/S004040391201341X

18. Kubik, S. Chem. Soc. Rev. 2009, 38, 585-605. http://pubs.rsc.org/en/content/articlepdf/2009/cs/b810531f

19. Gazit, E. Chem. Soc. Rev. 2007, 36, 1263-1269. http://pubs.rsc.org/en/content/articlepdf/2007/cs/b605536m

20. Santis, E. D.; Ryadnov, M. G. Chem. Soc. Rev. 2015, 44, 8288-8300. http://pubs.rsc.org/en/content/articlepdf/2015/cs/c5cs00470e

21. Zhang, Z.; Schreiner, P. R. Chem. Soc. Rev. 2009, 38, 1187-1198. http://pubs.rsc.org/en/content/articlepdf/2009/cs/b801793j

22. Xu, H.; Zuend, S. J.; Woll, M. G.; Tao, Y.; Jacobsen, E. N. Science 2010, 327, 986-990. http://science.sciencemag.org/content/327/5968/986

23. Custelcean, R. Chem. Commun. 2008, 295-307. http://pubs.rsc.org/en/content/articlepdf/2008/cc/b708921j

24. Piepenbrock, M.-O. M.; Lloyd, G. O.; Clarke, N.; Steed, J. W. Chem. Commun. 2008, 26442646. http://pubs.rsc.org/en/content/articlepdf/2008/cc/b804259d

25. Piepenbrock, M.-O. M.; Lloyd, G. O.; Clarke, N.; Steed, J. W. Chem. Rev. 2010, 110, 19602004. http://pubs.acs.org/doi/abs/10.1021/cr9003067 
26. McNally, B. A.; O’Neil, E. J.; Nguyen, A.; Smith, B. D. J. Am. Chem. Soc. 2008, 130, 1727417275.

http://pubs.acs.org/doi/abs/10.1021/ja8082363

27. Fischer, L.; Guichard, G. Org. Biomol. Chem. 2010, 8, 3101-3117.

http://pubs.rsc.org/en/content/articlepdf/2010/ob/c001090a

28. Thodarson, P.; Chem. Soc. Rev., 2011, 40, 1305-1323.

http://pubs.rsc.org/en/content/articlepdf/2011/cs/c0cs00062k

29. Haridas, V.; Lal, K.; Sharma, Y. K.; Upreti, S. Org. Lett. 2008, 10, 1645-1647.

http://pubs.acs.org/doi/abs/10.1021/ol8003386

30. Haridas, V.; Sahu, S.; Praveen Kumar, P. P.; Sapala, A. R. RSC Advances 2012, 2, 1259412605. http://pubs.rsc.org/en/content/articlepdf/2012/ra/c2ra21497k

31. He, Q.; Ao, Y.-F.; Huang, Z.-T.; Wang, D.-X. Angew. Chem. Int. Ed. 2015, 54, 11785-11790. http://onlinelibrary.wiley.com/doi/10.1002/anie.201504710/epdf

32. He, Q.; Han, Y.; Wang, Y.; Huang, Z.-T.; Wang, D.-X. Chem. Eur. J. 2014, 20, 7486-7491. http://onlinelibrary.wiley.com/doi/10.1002/chem.201400074/epdf 